Landslides (2021) 18:2935-2947

DOI 10.1007/s10346-021-01684-8

Received: 18 September 2020

Accepted: 26 April 2021

Published online: 8 May 2021

(c) The Author(s) 2021 lonut Cristi Nicu · Luigi Lombardo · Lena Rubensdotter

\section{Preliminary assessment of thaw slump hazard to Arctic cultural heritage in Nordenskiöld Land, Svalbard}

Abstract Permafrost-dependent landslides occur in a range of sizes and are among the most dynamic landforms in the Arctic in the warming climate. Retrogressive thaw slumps (RTSs) are enlarging landslides triggered by thawing and release of excess water from permafrost ground ice, causing smaller or larger collapses of ground surface, which in turn exposes new permafrost to rapid thawing and collapse. In this study, a preliminary assessment of previous thaw slump activity in Nordenskiöld Land area of Svalbard is made based on remote sensing digitisation of 400 slump-scar features from aerial images from the Norwegian Polar Institute (NPI). RTS properties and distribution are analysed with an emphasis on their implications for the preservation of the Svalbard's cultural heritage $(\mathrm{CH})$. Our analysis shows that the areas where RTS scars and $\mathrm{CH}$ co-exist in Nordenskiöld Land are, at present, limited and cover mainly areas distributed along north-west (Colesbukta, Grønfjorden, Kapp Starostin), north-east (Sassendalen and Sassenfjorden) and south-west (Van Muydenbukta) coastlines. Taking into consideration the preliminary aspect of this inventory and study, it can be stated that for now, RTS and $\mathrm{CH}$ sites do not have a high level of co-existence, except for eight sites which are located at less than $100 \mathrm{~m}$ to a RTS and one site that is located inside a currently inactive slump-scar. Further mapping of RTS will be undertaken in order to have a complete picture of these climate triggered landslides potentially threatening the Arctic $\mathrm{CH}$. The results of this study, even if preliminary, can be used by local authorities and stakeholders in prioritising future documentation and mitigation measures and can thus present a powerful tool in disaster risk reduction.

Keywords Permafrost - Retrogressive thaw slumps - Thermokarst - Remote sensing - Cultural heritage $\cdot$ Arctic $\cdot$ Svalbard

Introduction

Global climate change is resulting in an accelerating warming of the higher latitudes with dramatic changes expected and observed in the Arctic regions. The areas with permafrost have been in a particular focus of research in the last decade, with changes in the ground temperature having secondary effects on biology, hydrology, carbon release and general ground stability (Lewkowicz and Way 2019). The sub-Arctic and Arctic coastal landscapes are especially sensitive to climate change-induced morphological processes, from which they were previously protected due to the permafrost and seasonal sea ice. Permafrost (perennially frozen ground) is defined as ground that has remained below $0^{\circ} \mathrm{C}$ for at least 2 years (Schuur et al. 2015); roughly $24 \%$ of the land surface in the northern hemisphere is covered by permafrost (Nitze et al. 2018). The rapidly increasing temperatures in the Arctic regions since the beginning of the 1970 s have caused areas of permafrost to increase in internal temperature and sometimes thaw completely (Biskaborn et al. 2019). Both these changes have a potential effect on ground stability in both flat and steep areas. The most common permafrost stability disturbances are active layer detachment (ALD) slides and retrogressive thaw slumps (RTS, Fig. 1a) (Cassidy et al. 2017), which both can be termed forms of thermokarst. The process for surface dynamics in the Arctic is based in the fluctuation of seasonal freeze and thaw in the uppermost layer of the permafrost-the active layer. Seasonal thaw of the active layer melts surface ground ice in the summer, which then refreezes in the winter. The seasonal thaw may, by itself or together with precipitation, result in local oversaturation of the soil (all pore spaces filled with water), which in turn loses its shear strength, collapses and initiates slides or slumps on slopes (Fig. 1b). An initial failure will expose new frozen ground to continued thaw and potential failure, leading to the development of a larger thaw slump (TS). TS can also be initiated in a similar way along an erosive riverbank or shoreline, or in a thermokarst gully, where fluvial erosion exposes ice rich frozen ground to continued thawing. If a TS remains active over several seasons, it may develop and retrograde further and is then called a retrogressive thaw slump (RTS) (Fig. 1a). The depth of the sliding plane in a TS and RTS (henceforth combined and called RTS) is dependent on the thaw depth on the year of activity and may thus vary between years and depending on the properties of the failing soil mass.

RTS have a bimodal shape of a steep backwall, low-angle bottom (sliding surface, Fig. 1a) and a tongue of displaced saturated soil, which has been partly or completely reworked in the movement process. Since they are mostly released in contact with a fluvial channel or coastline, the slump deposit is generally transported away rapidly leaving the slump scar, which is more permanent in the landscape. The processes will likely initiate the subsequent years since the vertical back-scarps will be unstable to gravitation as soon as the active layers have started to develop. RTS-type features may continue to expand through head scarp retrogression until some change in the substrate or thermal conditions of the ground halts the process. They may also stop developing if displaced vegetation buries and insulates the ice-rich headwall scarp from continued thaw (Wang et al. 2016). Welldeveloped RTS scars can be easily recognised in the landscape because they commonly appear as horseshoe-shaped depressions (Fig. 1a) with a different surface pattern than the surroundings, often connected at one end to a river or shoreline (Lacelle et al. 2010). RTSs can cause serious damage to infrastructure and are known to modify the discharge of streams and rivers (Kokelj et al. 2013), among other effects. Moreover, RTS may represent a significant source of carbon release to the atmosphere (Turetsky et al. 2020). RTSs are documented throughout the cold regions of the globe: Canada (Lacelle et al. 2010; Wang et al. 2016; Cassidy et al. 2017), Tibet Plateau (China) (Niu et al. 2012; Sun et al. 2017), Siberia (Russia) (Séjourné et al. 2015) and Alaska (USA) (Swanson and Nolan 2018). In recent years, significant progress has been made in improving identification and mapping of RTS 

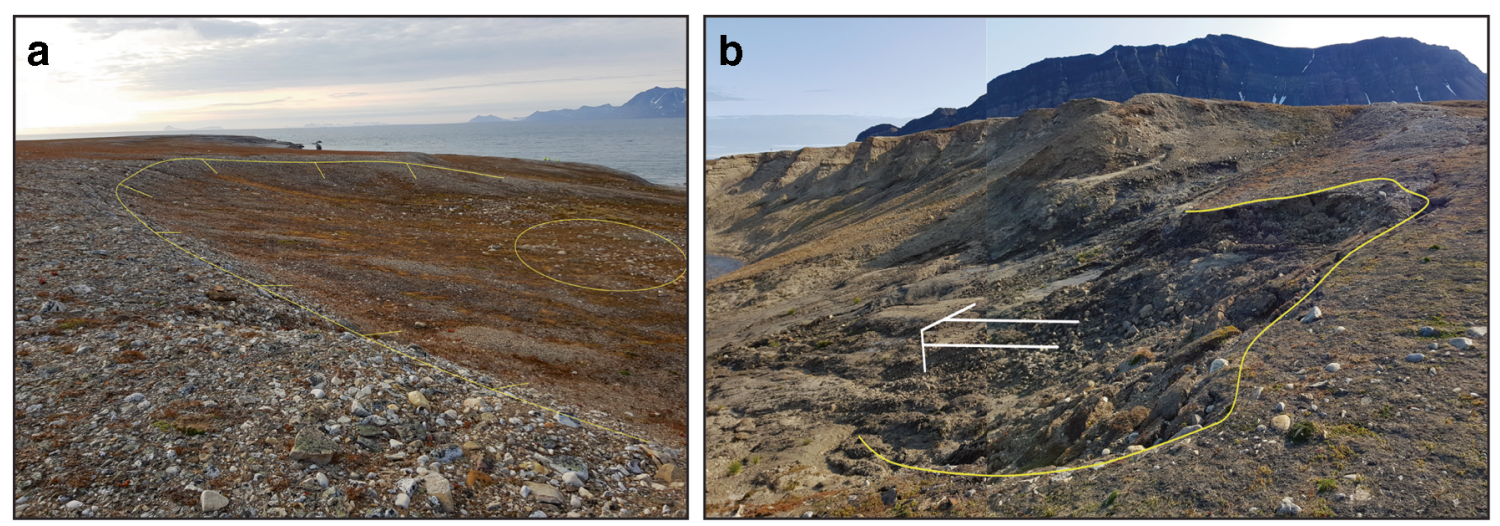

Fig. 1 Thaw slumps and retrogressive thaw slumps back scarps. a Inactive RTS-scar with a softened profile in the back-scarp due to subsequent solifluction and vegetation; encircled is an area on the gently sloping bottom of the scar with larger particles remaining after the water slump has presumably removed smaller particles; $\mathbf{b}$ active thermokarst slump in a river bank; direction of displaced mass indicated with arrow

with the following remote sensing techniques: photogrammetry (Swanson and Nolan 2018), satellite SAR interferometry ( $\mathrm{Hu}$ et al. 2019) and deep learning (Huang et al. 2020).

In addition to direct threat from climate change (Fatorić and Seekamp 2017), cultural heritage $(\mathrm{CH})$ sites at a global level are threatened by a set of geohazards, e.g. landslides (Nicu and Asăndulesei 2018), gully erosion (Nicu 2019), coastal erosion (Nicu et al. 2020) as well as anthropogenic land use pressure (Nicu and Stoleriu 2019). The way landslides affect $\mathrm{CH}$ has been detailed in numerous studies across the world (Margottini 2004), from slow moving landslides (Capizzi and Martorana 2014) to rapid landslides (Tarragüel et al. 2012). These processes affect a large spectrum of immovable $\mathrm{CH}$ sites, especially built $\mathrm{CH}$ and buried archaeological sites (Nicu 2017).

The direct effects of climate change on $\mathrm{CH}$ may be immediate or cumulative and are more exacerbated in Arctic areas (Hollesen et al. 2018). One of the most exposed Arctic areas to climatic changes is Svalbard, which is experiencing climatic changes to a much larger extent, compared to the global average (van Pelt et al. 2019). In Svalbard, most of the existing $\mathrm{CH}$ sites are located along the coastlines and low-lying areas due to the historic type of human activity (whaling, hunting and mining). $\mathrm{CH}$ exposed to climate change-induced hazards can be used to communicate a larger message about climate action. Identifying threatened heritage is an effective way of communicating the urgency of the immediate and future impacts of climate change to the general public. Also, $\mathrm{CH}$ is an important source of societal resilience and an asset in climate action (Council of the European Union 2020). Historic structures, sites and past landscapes management also have much valuable information to offer on how past societies adapted to previous climatic changes (Mihu-Pintilie and Nicu 2019; Nicu et al. 2019).

Although there is a good knowledge of permafrost ground instability in Canada, Tibet Plateau, Siberia and Alaska, there is little known about the RTS activity in Svalbard (i.e. spatial distribution, density, size), and even less consideration is given to $\mathrm{CH}$ sites. Therefore, within this study, we will focus on analysing, for the first time globally, the TS from Nordenskiöld Land (Svalbard) and their implications for $\mathrm{CH}$ sites. The results of this study, even if preliminary, will be used to evaluate the present state of $\mathrm{CH}$ sites and disaster risk reduction. They will be a powerful tool for stakeholders and local authorities in prioritising future mitigation measures.

\section{Study area and cultural heritage practices in Svalbard}

\section{Study area}

The study area is located in central Spitsbergen (Fig. 2a), which constitutes the largest island of the Svalbard archipelago. The Svalbard archipelago is located between Northern Norway and North Pole (Sessford 2013). Locally, the study area is named the Nordenskiöld Land area $\left(78^{\circ} \mathrm{N}, 15^{\circ} \mathrm{E}\right)$ (Fig. $2 \mathrm{~b}$ ) and has a surface area of approximately $4000 \mathrm{~km}^{2}$. Parts of Nordenskiöld Land are protected as a national park with the purpose of protecting habitats, species, ecosystems, natural ecological processes and landscapes and of facilitating research. The national park includes vast areas of continuous and rich vegetation and moss flora, wetlands and shallow sea areas suitable for breeding birds and geological outcrops of interest (Regulation 2003). The fauna is characterised by reindeer, polar bears, walruses, arctic foxes and a significant number of migratory birds during the summer season; the goose population has been stable, while the reindeer population has had a moderate increase during the last few decades (Johansen and Tømmervik 2014).

The geology of Svalbard is varied and complex and covers all the geological periods. The bedrock geology and fault system controls most of the landscape. The highest mountains ( $>1000$ $m$ a.s.l.) are located in the central part of Nordenskiöld Land, with the highest altitude being at Gustavfjellet mountain (1235 $\mathrm{m}$ a.s.l), located north of the mining settlement of Svea (Humlum 2002). The maximum altitude declines to about $700 \mathrm{~m}$ a.s.l. towards the eastern and western sides of the study area. The geography of the central Svalbard landscape is characterised by plateau mountains with distinct separate plateau and summit levels determined by horizontally or sub-horizontally layered sedimentary rock units. To the west, the area has experienced folding and faulting resulting in more steeply angled strata and correspondingly sharper alpine profiles. The plateau landscape is dissected by wide glacial valleys between steep gravitationally active hillslopes and some cirque and valley glaciers in the heads of the valleys. 


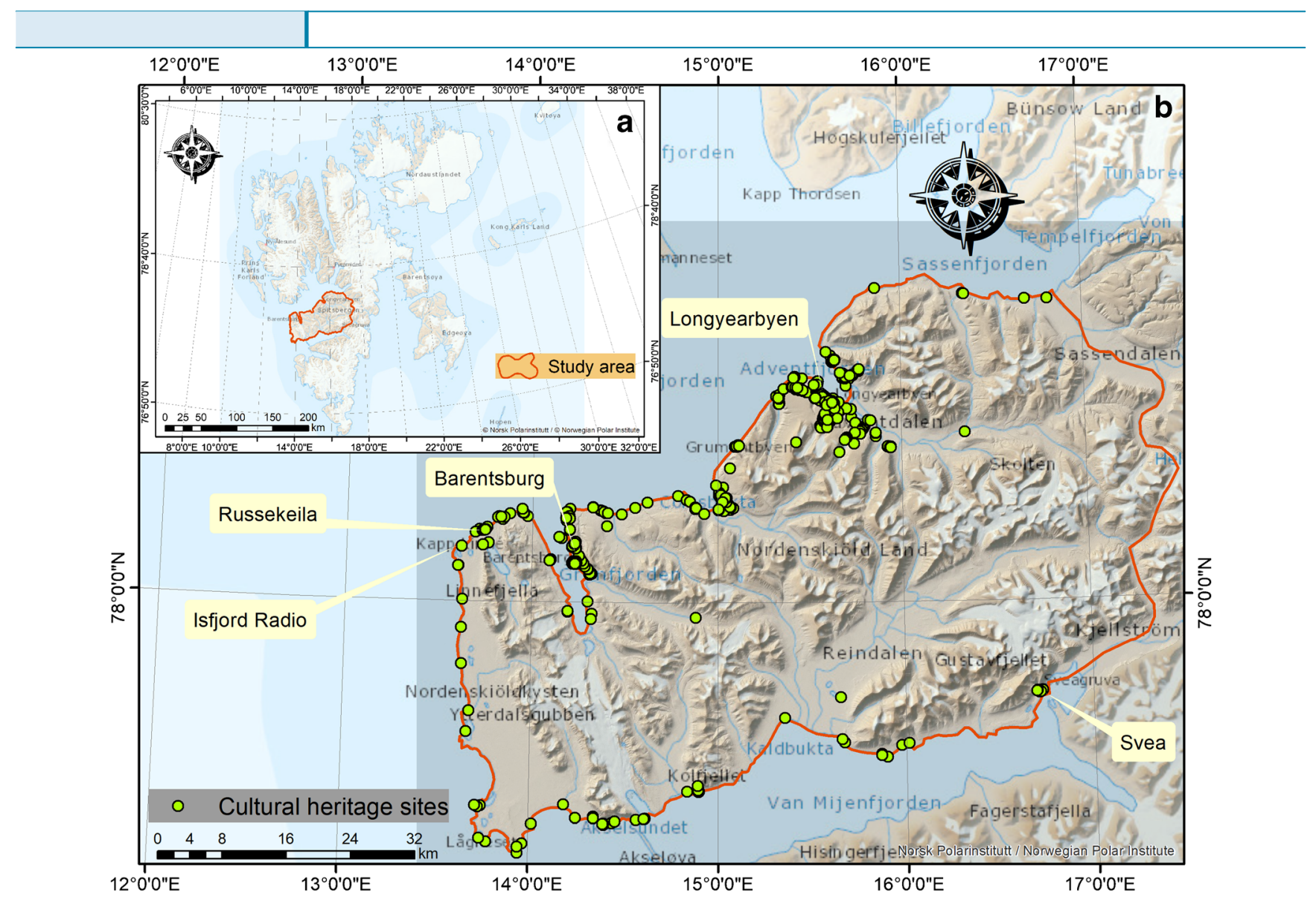

Fig. 2 a Geographical location of the study area on Svalbard; $\mathbf{b}$ detail over the study area and the location of the cultural heritage sites (base map from Norwegian Polar Institute)

The mean annual temperature at Isfjord Radio (Fig. 2b) varied from -1.0 in $2011-2012$ to $-3.2^{\circ} \mathrm{C}$ in $2008-2011$, with an average of $-2.3^{\circ} \mathrm{C}$, which indicates an active periglacial climate (Eckerstorfer et al. 2017), while the mean annual temperature in the main settlement, Longyearbyen, central Spitsbergen, is $-5^{\circ} \mathrm{C}$, and the mean annual precipitation is $190 \mathrm{~mm}$, for the period 1975-2000 (Humlum 2002). However, there is a significant east-west precipitation gradient, and at Isfjord Radio, $50 \mathrm{~km} \mathrm{SW}$ of Longyearbyen, the mean annual precipitation is $435 \mathrm{~mm}$, which is more than twice the precipitation in Longyearbyen. These variations have effects on thickness of Svalbard's permafrost (Lousada et al. 2018), which is known to be highly influenced by topographical features, such as altitude, glacial cover, slope and aspect. It has been observed and calculated that permafrost thickness ranges from less than 100 near the coasts to more than $500 \mathrm{~m}$ in the highlands (Humlum et al. 2003).

Svalbard is governed by a representative of the Norwegian federal government, the Sysselmannen (Governor) of Svalbard (GOS), and the main settlements in the Nordenskiöld Land are Longyearbyen (2000 inhabitants live there, which makes it the largest settlement on Svalbard), Barentsburg (400 inhabitants) and Svea (a mining town in the process of closing down) (Fig. 3b). The GOS ensures that any activities taking place on Svalbard are in line with the Norwegian national security and safety regulations; this also applies to all $\mathrm{CH}$ and natural values of the archipelago (Sysselmannen 2016).

\section{Cultural heritage on Svalbard}

The Arctic environment has been considered ideal for long-term preservation of archaeological remains, both for artefacts and environmental proxies (Hollesen et al. 2018). The Svalbard Environmental Protection act states that all anthropogenic remains from before 1946 are automatically protected and considered $\mathrm{CH}$ sites, along with $100 \mathrm{~m}$ buffer zone around them. The buffer zone has the same significance as the site itself (Arlov 1989). This includes remains from different activities such as whaling, hunting and trapping, mining, scientific exploration, plane wrecks from World War II, human graves, including crosses and other grave markers, bones and bone fragments found on or below the ground surface (Governor of Svalbard 2020). According to the Norwegian national heritage database (Askeladden - Riksantivaren 2020), the Nordenskiöld Land area contains 872 confirmed $\mathrm{CH}$ points, which represents about $10 \%$ of the Svalbard total (Fig. 2b); the historic remains in Svalbard are considered international $\mathrm{CH}$ (Hacquebord 2001). A recent study focussing on shoreline processes threatening $\mathrm{CH}$ (Nicu et al. 2020) emphasises the need for geomorphological understanding of RTS analysis and mapping in this regard.

Since $\mathrm{CH}$ on Svalbard is dominated by fragile wooden structures, and gravitational TS and RTS are a real threat, this study fulfils the need to shed light on such thermokarst occurrences and distribution within the Arctic landscape of Svalbard. The 


\section{Technical Note}

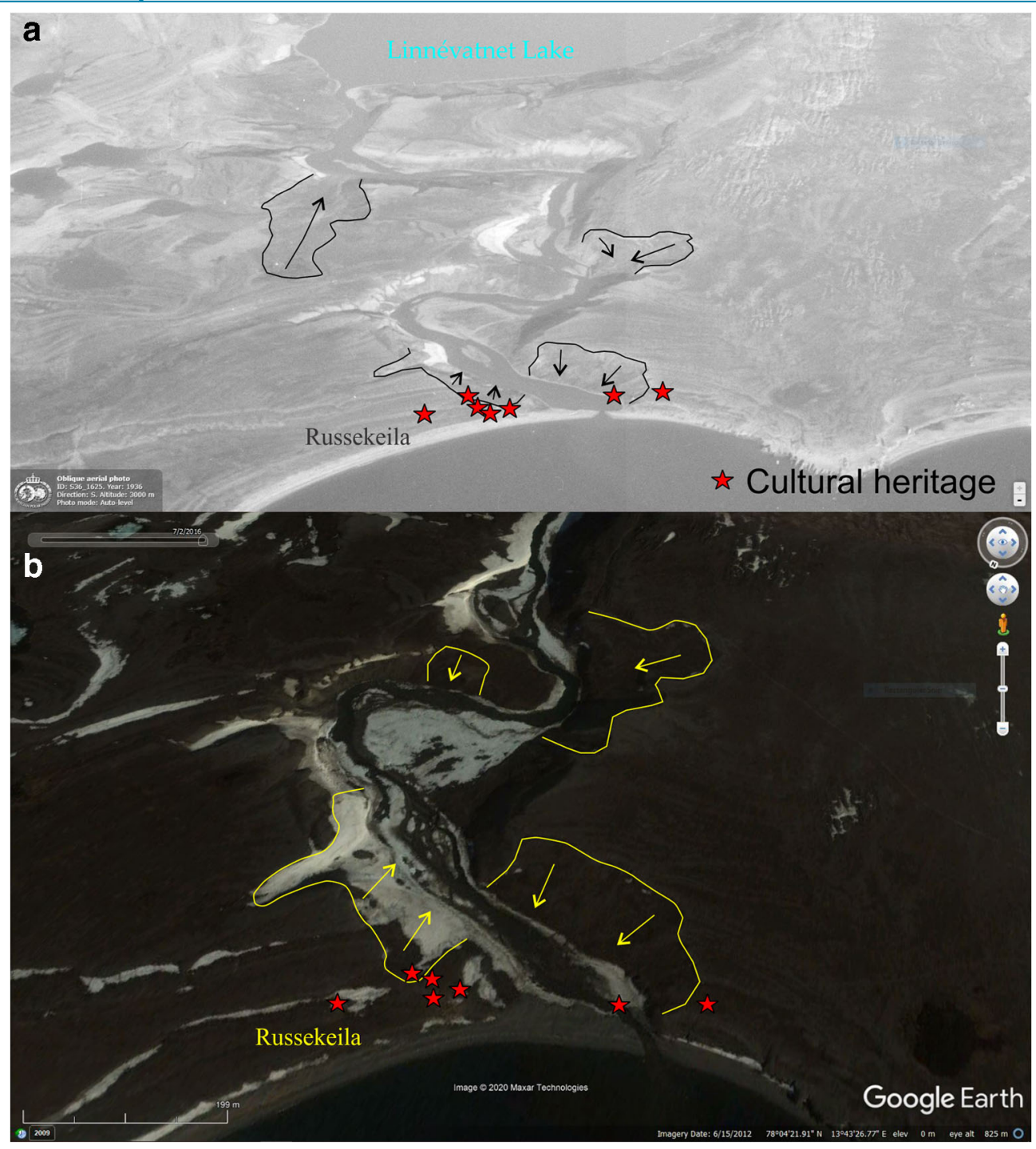

Fig. 3 Example of $\mathrm{CH}$ sites in close proximity of retrogressive thaw slumps at Russekeila (Kapp Line); a detail of retrogressive thaw slumps scars and cultural heritage on an aerial image from 1936 (image courtesy: Norwegian Polar Institute); b retrogressive thaw slumps scars and cultural heritage on an aerial image from 2016 (Google Earth)

GOS considers conserving $\mathrm{CH}$ among the most significant environmental goals; therefore, depicting $\mathrm{CH}$ relations with the TS and RTS is an important task (Dahle et al. 2000). A good example in this regard is the $\mathrm{CH}$ from Fig. 3 located in close proximity to several RTSs at Russekeila (Kapp Line), as it is visible on aerial images from 1936 (Fig. 3a) and from 2016 (Fig. 3b).

\section{Materials and methods}

Since the aim of this study was a first estimate of the potential threat to Svalbard $\mathrm{CH}$ by thaw slumps in a warming permafrost and climate regime, the initial step was to create a database of present thaw slump occurrences (morphological RTS scars; also named slump scars). The next step was geographical and statistical analysis of the slump scar properties and their relation to the $\mathrm{CH}$ sites.

\section{Mapping of thermokarst slumps from aerial images}

To build an inventory of previous RTS in the study area, we interpreted orthophotos acquired in 2009-2011 (there is no recent imagery available) and made accessible from the Web Map Services (WMS) developed by the Norwegian Polar Institute (NPI) (Norwegian Polar Institute / USGS Landsat 2020). The RTS scars were digitised as polygons, using the on-screen digitisation method within the ArcGIS 10.4.1 version (ESRI, Redlands, CA, USA). However, this is still a work in progress, and a much larger area will be examined in the future. All data was integrated into a GIS using the WGS_1984_UTM_Zone_33N reference system. Different analyses of slump scar parameters were performed after the digitisation process; this involved the calculation of size characteristics (Jibson and Tanya $\square$ 2020), as well as shape indices (area, maximum distance and elongation index). The maximum distance is calculated between two points along the slump scar perimeter. 
The elongation index is calculated as the maximum distance divided by the root square of the area (Castro Camilo et al. 2017).

The slump scar shape offers important information about the slump's stage of evolution. Because RTS are landslides that have a unique failure mechanism, it is important to understand whether they behave according to power laws that are typical of landslide populations triggered in non-Arctic contexts (Tanya $[$ et al. 2019) and to understand the equivalent event magnitude (mLS) (Tanya et al. 2018). As they develop backwardly with respect to the initial movement direction, they tend to assume a more elongated shape over time, with a larger length-to-width ratio (Highland and Bobrowsky 2008). In this study, a frequency-area (or volume) distribution (FAD) was also performed; the FAD of a landslide event quantifies the number of landslides that occur at different sizes (Malamud et al. 2004).

In addition to the overall statistics of slump scar size, shape characteristics and elongation ratio and retrogressive nature of development, slump scar spatial distribution is even more crucial for projective analysis, with respect to $\mathrm{CH}$ hazard. For this reason, we have examined whether RTS and $\mathrm{CH}$ sites overlap within the same geographic space, in which case the $\mathrm{CH}$ would be at risk. This was done by exploring their respective spatial densities (expressed in number per $\mathrm{km}^{2}$ ) and the terrain properties of the landscape they occupy. The terrain properties were derived from the Digital Elevation Model (DEM) with $5 \times 5 \mathrm{~m}$ pixel size, accessible from the Web Map Services (WMS) developed by the Norwegian Polar Institute (NPI) (Norwegian Polar Institute 2020). Analysis of terrain properties was derived from common landslide susceptibility studies, as the study area was partitioned into a regular squared lattice with a $30-\mathrm{m}$ resolution. A presence/absence status was assigned to every grid-cell falling inside a slump scar or $\mathrm{CH}$ polygon. This binary information was used to extract the distribution of a set of terrain attributes and support the interpretative phase of this study. In order to complement the purely spatial overview, we retrieved the morphometric characteristics associated with the RTS and $\mathrm{CH}$ locations and the characteristics of the remaining terrain. This was done by examining the dual information of presence/absence terrain attributes (elevation, slope, Eastness, Northness, relative slope position (RSP), planar curvature (PLC), profile curvature (PRC) and Topographic Wetness Index (TWI)), which are commonly used in landslide susceptibility studies (Lombardo and Mai 2018). Following this, a classic quantile-quantile (QQ) plot (Tarolli et al. 2012) was made in order to examine whether the two distributions (RTS and $\mathrm{CH}$ ) are compatible.

\section{Cultural heritage data}

Cultural heritage data of $872 \mathrm{CH}$ items in Nordenskiöld Land (out of the 8300 totals in Svalbard) was retrieved from the Norwegian national heritage database, Askeladden-Riksantikvaren. The items are registered as polygons. Taking into consideration the Svalbard protection regulations regarding the area surrounding $\mathrm{CH}$ sites, an additional 100-m buffer area was computed around the polygons; this was also used to check how many $\mathrm{CH}$ sites (including the buffer areas) intersect an RTS scar. Then the results of the slump scar mapping was combined with the location of the $\mathrm{CH}$ sites in order to understand potential implications of RTS on $\mathrm{CH}$ in Nordenskiöld Land, Svalbard.
Results

\section{RTS data analysis}

Figure 4 shows the RTS scars mapped in Nordenskiöld Land, presented as point features (for a better visual assessment). In total, 400 scars were mapped. Figure 5 shows the slump scar size characteristics in a traditional FAD plot. The power law exponent is approximately -2.2 , which aligns well with analogous landslide inventories mapped in non-Arctic landscapes (Malamud et al. 2004). The plot relates every binned class of landslide size with the corresponding frequency, offering an overview of the inventory size characteristics (Guzzetti et al. 2012) and completeness (Tanya and Lombardo 2020). As for the associated mLS, it is overall a relatively small event magnitude. One element of the RTS scar size characteristics is unusual. Reading the plot on the $x$-axis from right to left, the frequency ( $y$-axis) usually increases up to a point where very small landslides drastically decrease in numbers. This inflection occurs at the so-called rollover point, and it is a characteristic of the vast majority of landslide inventories in nonArctic landscapes. The literature has justified this behaviour for two reasons. First, the FAD trend theoretically implies that smaller landslides should indefinitely increase in numbers. However, this assumption does not hold because of scale-dependent relations such as cohesive forces in soils, which at very fine scales act to neglect the occurrence of any failure mechanism, or small landslides. Second, this assumption does not hold also because it does not consider our ability to identify and map small landslides through remote sensing. Orthophotos and satellite images will always have a finite resolution, which implies that our capacity to interpret and map landslides must have a boundary condition after which no landslide will be visible (Li et al. 2016). In Fig. 5, instead of a typical inflection after the rollover point, the frequency of landslides stays almost constant from approximately $10^{3} \mathrm{~m}^{2}$ to the smallest observed RTS. Our explanation of such behaviour cannot be associated with the limitation in satellite image resolution. In fact, the orthophotos from which we mapped the RTS have an approximate resolution of $0.25 \mathrm{~m}$. Therefore, the only reasonable explanation for the absence of the typical inflection after the rollover point has to do with the physics behind the RTS genesis and evolution.

The slump scar size information is complemented in Fig. 6, where the distribution of three shape indices (area, maximum distance and elongation index) extracted from the inventory is highlighted. The left panel shows the actual distribution of slump scar extents, which appears to be positively skewed and heavily tailed. One of the most striking characteristics is shown in the geographical example, where one of the largest RTS scars in the study area (left panel) is far from the catchment ridge and occupies a region gently sloping towards north. The central panel shows the maximum distance parameter. In this case, one of the longest RTS examples $(600 \mathrm{~m})$ is geographically shown to evolve by retrograding over a very long distance, and it also initiated in near-flat conditions. The same is shown in the right panel, where one of the most rounded RTS occurs right at the foothill of the mountain.

Overall, few RTS scars appear to be larger than $20,000 \mathrm{~m}^{2}$ and longer than $300 \mathrm{~m}$, and scars are primarily rounded. The elongation index is shown in the right panel, where large values imply a longer axial shape, whereas small values tend to be attributed to 


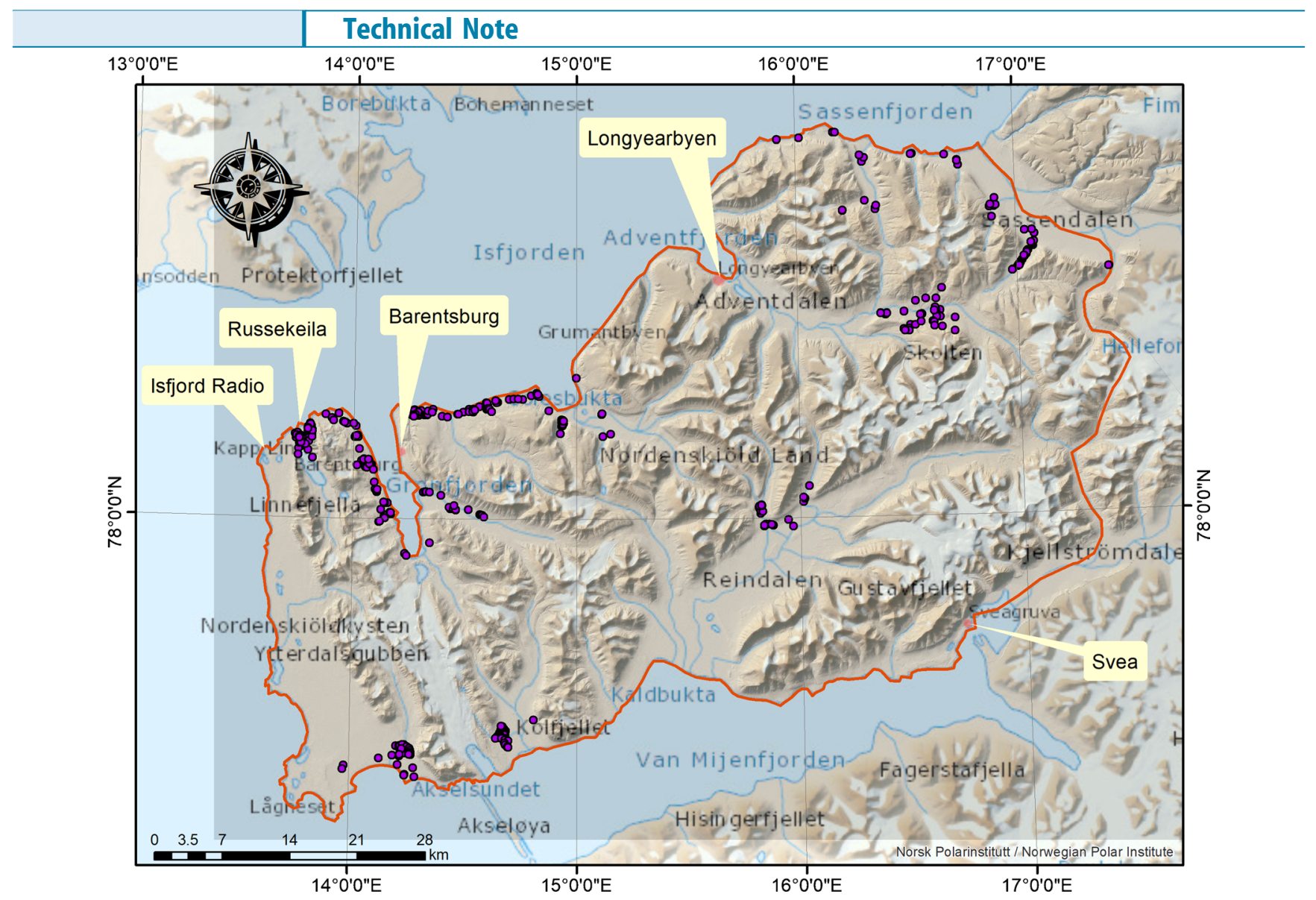

Fig. 4 Mapped thaw slump scars (thaw slumps and retrogressive thaw slumps) in the study area represented as point features for a better visual assessment

the round slump scars. A large proportion of relatively small slump scars in our dataset (more TS than RTS) may indicate that most of the RTS have had a short to very short development time, because they did not have enough time to retrograde, reaching larger elongated shapes.

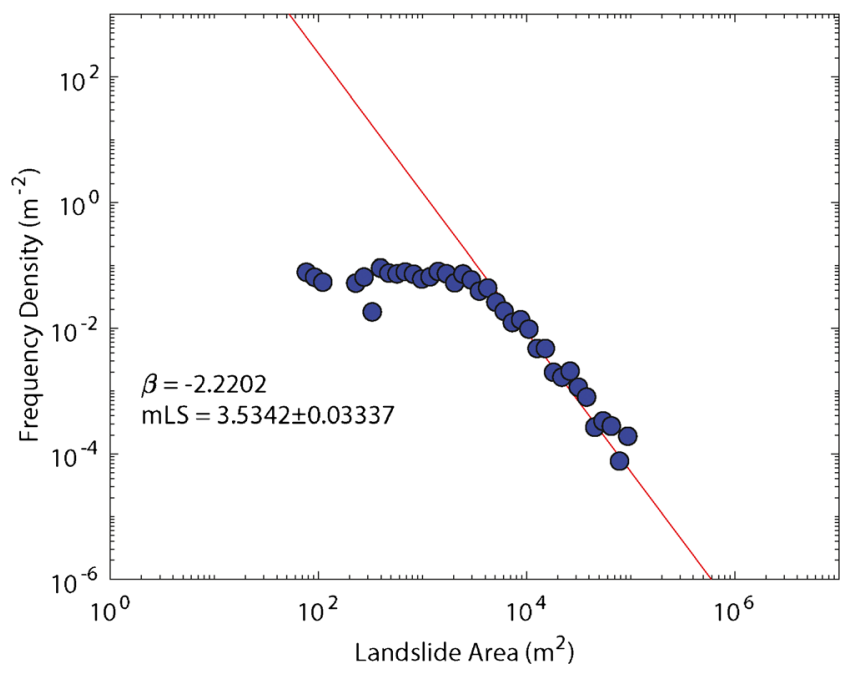

Fig. 5 Frequency area distribution obtained for the retrogressive thaw slumps inventory in Nordenskiöld Land

\section{CH data analysis}

This preliminary overview presented in the last chapter explains "how" RTS scars appear, but it lacks the necessary information on "where" they are located, and more importantly "if" their geographical locations threaten $\mathrm{CH}$ sites within the study area. Figure 7 shows an overview of the spatial densities of both slump scar and $\mathrm{CH}$ sites. It can be observed that they do not significantly overlap, with the exception of the north-west (Colesbukta, Grønfjorden, Kapp Starostin), north-east (Sassendalen and Sassenfjorden) and south-west (Van Muydenbukta) coastlines. Regarding the main human settlements in the study area, Longyearbyen (Adventfjorden) and Barentsburg (Grønfjorden), where very high densities of $\mathrm{CH}$ occur, there are no significant threats from RTS at this stage of the study. Other concentrations of $\mathrm{CH}$ can be observed in Svea, a soon to be an abandoned coal mining settlement, located in the south-eastern part of the study area. High slump scar densities occur in the north-eastern part (Eskerdalen, upper side of Adventdalen), in the central part (Sørhytta) and in the south-western part with two "hot-spots" in close proximity of Kapp Schollin and on both sides of Ytterdalselva river into Van Muydenbukta bay. Other areas with high densities are in the north-western part of the study area on the left side of Grøndalen, the territory between Kapp Dresselhuys and Colesbukta (highlighted in Z1, Fig. 7) and the territory between Kapp Mineral and Grønfjorden. 


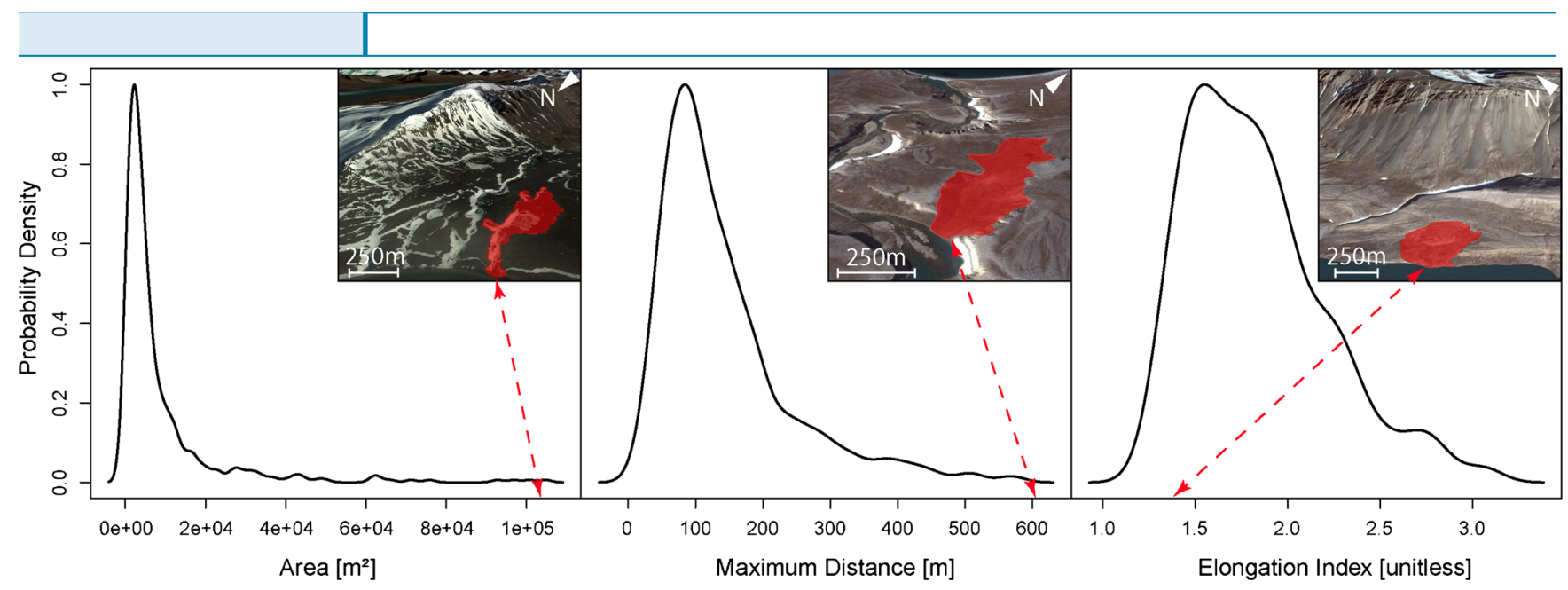

Fig. 6 Probability density functions obtained for three retrogressive thaw slumps shape parameters (aerial captions show three selected retrogressive thaw slumps examples)

To complement the purely spatial overview of the features, in Fig. 8, we retrieved the morphometric characteristics associated

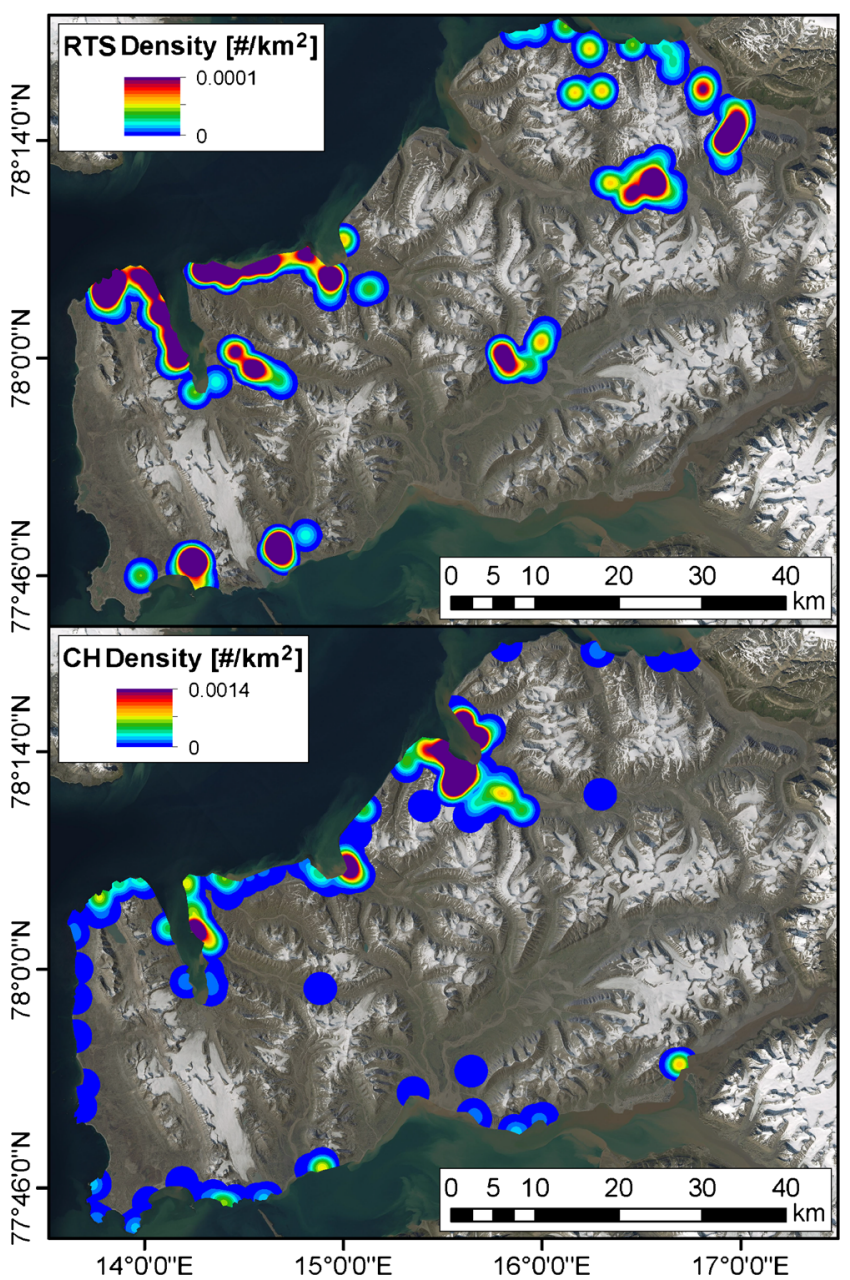

Fig. 7 Computed spatial densities of retrogressive thaw slumps (upper panel) and cultural heritage sites (lower panel) with the slump scar and $\mathrm{CH}$ locations and the characteristics of the remaining terrain. The presence/absence conditions for both types of sites show notably similar patterns. For example, RTS and $\mathrm{CH}$ sites are present in locations exposed to the east-west direction (Eastness) with a distribution that is nearly identical to the rest of the study area. An analogous situation is that on the Aklavik Plateau, Canada, where RTS are mostly developed on western slopes and gently sloping terrain (Lacelle et al. 2010). The same distribution pattern is valid in terms of north-south direction (Northness), as well as Planar (PLC) and Profile Curvatures (PRC) and Topographic Wetness Index (TWI).

Only three properties show a distinct pattern (elevation, relative slope position and steepness), where the boxplots associated with the presence of RTS and $\mathrm{CH}$ are significantly different than the boxplots where the RTS and $\mathrm{CH}$ are absent. The elevation confirms our previous statement that RTS and $\mathrm{CH}$ sites are primarily located along the coastline. The bulk of both RTS and $\mathrm{CH}$ distributions is centred a few tens of metres above the sea level, whereas NORTS scar and NO-CH locations exhibit a much larger variability. The very same information is conveyed by the Relative Slope Position (RSP). This terrain attribute is essentially a normalised height, where values close to zero are assigned to lowland or at the foot of the slope and values close to one are assigned to the ridge tops. The RSP shows an even larger discrepancy for locations where RTS and $\mathrm{CH}$ are present or absent, with the former status being confirmed in the lowest portions of the topographic profile. The property that shows the most obvious evidence of the unique RTS failure mechanism is the slope steepness. Usually, landslides of any other type (Hungr et al. 2014) occur in much steeper slopes (e.g. debris flows from $21^{\circ}$ (Iverson 1997) or falls and topples at even higher angles (Fall et al. 2006)), yet the bulk of the RTS presence distribution appears to be confined within $0-10^{\circ}$. As for $\mathrm{CH}$ sites, these show a similar trend between presence and absence cases, although the presence distribution shows a higher variation compared to the RTSs.

This overview points out some significant differences in the terrain attributes when assessing where RTS and $\mathrm{CH}$ are present or absent across Svalbard's arctic landscape. At the same time, it has shown some degree of similarity between RTS and $\mathrm{CH}$ presence 


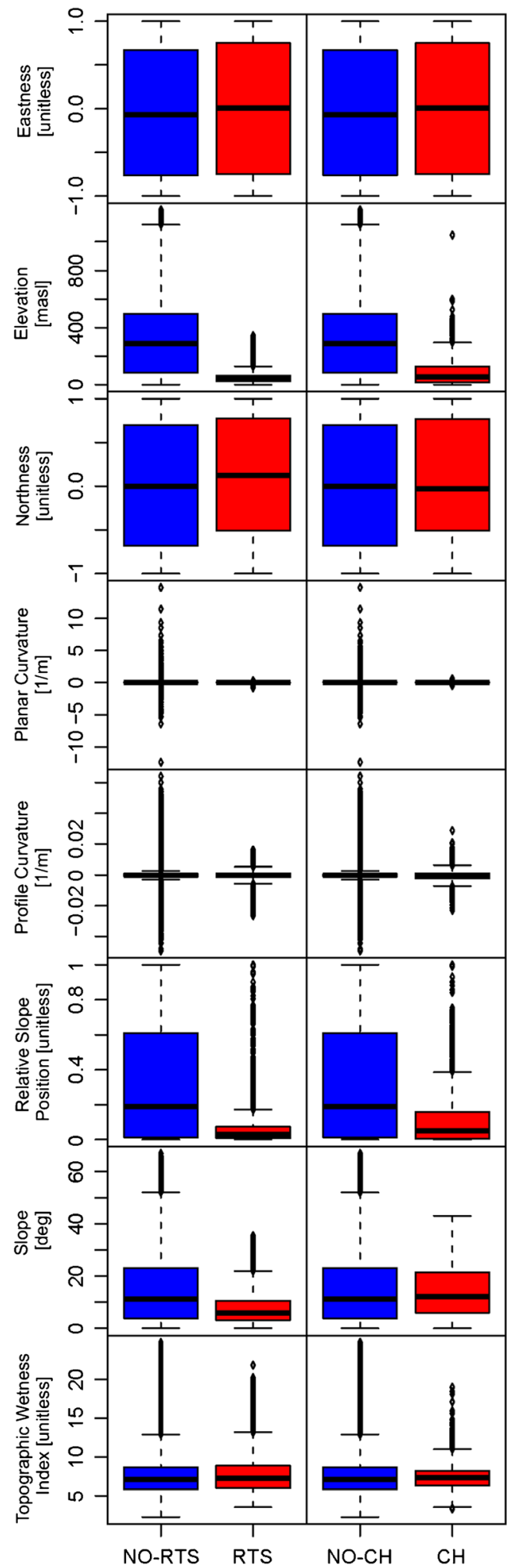

Fig. 8 Box-plots of the binarized stable/unstable information on retrogressive thaw slumps (NO-RTS, absence; RTS, presence) and cultural heritage (NO CH, absence; $\mathrm{CH}$, presence) with respect to a set of morphometric characteristics typical for landslide susceptibility studies conditions, which suggests a need for further examination. Svalbard was pressed down by the weight of ice sheets at the last glaciation and has, since then, experienced a post-glacial uplift. Precise dates and elevations are sparse, but central Nordenskiöld Land has had an approximate net sea level change of ca. $-65 \mathrm{~m}$ since the last deglaciation (Lønne 2005), meaning the lower areas in many cases consist of uplifted sea bottom with glaciomarine and marine sediments. Such sediments generally contain sorted, fine-grained units, which are favourable for accretion of ground ice and which, when experiencing high pore-water pressure and gravitational mobilisation, have low internal friction between grains. Uplifted marine sediments also have a flat or low angle surface, fitting with the findings from the RTS analysis.

With emphasis on the elevation, RSP and slope, Fig. 8 shows the respective distributions of RTS scars and $\mathrm{CH}$ independently from each other and saturated because of large values plotted along the $y$-axis and of the larger values range extracted from the absence cases. Therefore, the preliminary investigation was deepened in order to study whether the distributions of elevation, RSP and Slope, calculated for RTS and $\mathrm{CH}$, share the same characteristics. This was done by plotting each RTS and $\mathrm{CH}$ distribution against each other, in a traditional quantile-quantile (QQ) plot (Fig. 9). A QQ plot represents a common tool to examine whether two distributions are compatible. Despite the similarity implied in Fig. 8, Fig. 9 shows a situation where RTS and $\mathrm{CH}$ presence conditions do not appear to share the same landscape with respect to the three attributes under examination. The QQ plot of the elevation (left panel) suggests that RTS and $\mathrm{CH}$ share the same distribution up to $300 \mathrm{~m}$ a.s.l. and after this threshold $\mathrm{CH}$ is shown to be present at higher elevations. This is further differentiated for the RSP (middle panel) and slope (left panel) QQ plots, where RTSs appear to be present much lower along the topographic profile and steepness values generally smaller than the $\mathrm{CH}$ counterpart. Here, it should be stated that this is a preliminary study over the RTS presence in Nordenskiöld Land and that the database of RTS is still to be completed in the near future. Regarding the low degree of RTS directly co-existing with $\mathrm{CH}$, this may sound reassuring; however, $\mathrm{CH}$ in Svalbard is represented by immovable objects, whereas the RTS activity and area may be expected to expand as the permafrost warms and thaws.

\section{$\mathrm{CH}$ in danger}

Most of the Svalbard's CH sites are located near or next to the coastline due to specific human activity using the sea as transport route that included hunting wales and walruses, trapping, mining and transport ports (Nicu et al. 2020). However, the sea is also one of the main drivers of local temperature changes, which in turn contributes to permafrost degradation and potential RTS activity. Therefore, although the current situation is not alarming, newly triggered RTS as well as pre-existing ones may still activate/reactivate, retrograde and damage cultural remains (Fig. 10). Following the intersection analysis, it was concluded that out of $872 \mathrm{CH}$ items, nine are the most vulnerable to thaw slump action (Table 1). The most vulnerable $\mathrm{CH}$ site, the Polish research cabin, site ID 152075-1, is located within an RTS body (Fig. 10a). This represents the $\mathrm{CH}$ that is the most exposed; presently, the cabin is not in good shape, and the exterior walls are almost collapsing (Fig. 10e). This could be both from the permafrost active layer movement and the lack of preservation measures. The next most 

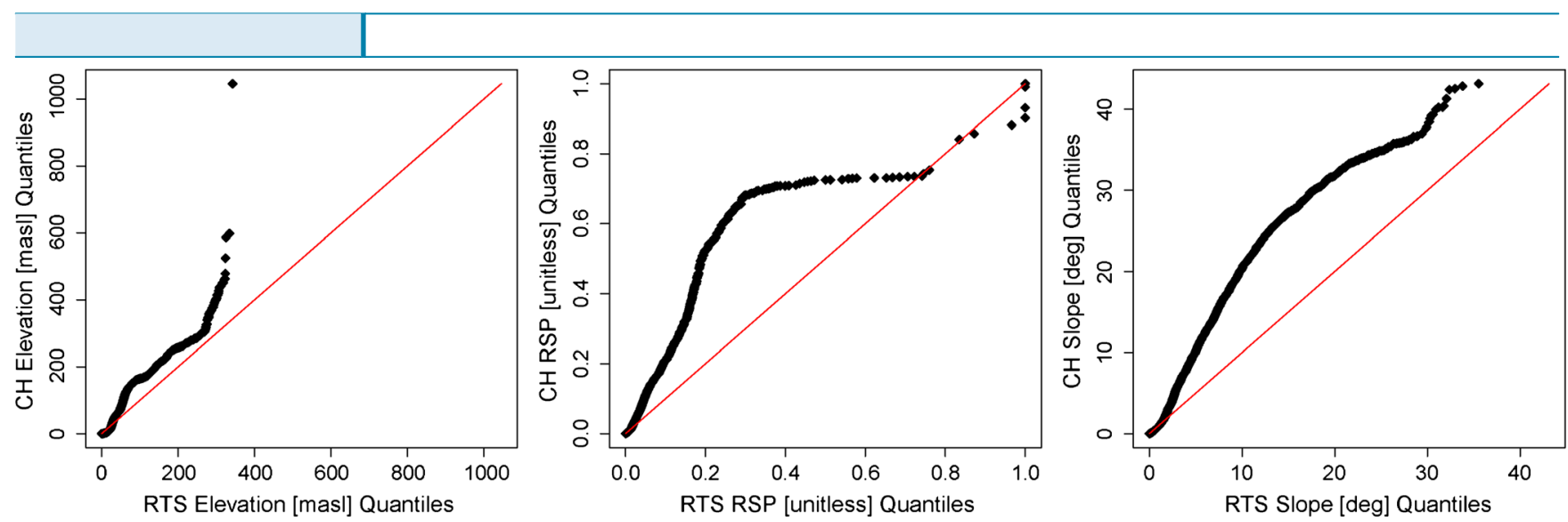

Fig. 9 Quantile-quartile plots of elevation, RSP and slope steepness, whose distributions are compared for retrogressive thaw slumps and cultural heritage; the red solid line indicates the perfect match between two theoretical distributions, whereas each black diamond corresponds to a given percentile calculated from the retrogressive thaw slumps and cultural heritage distributions
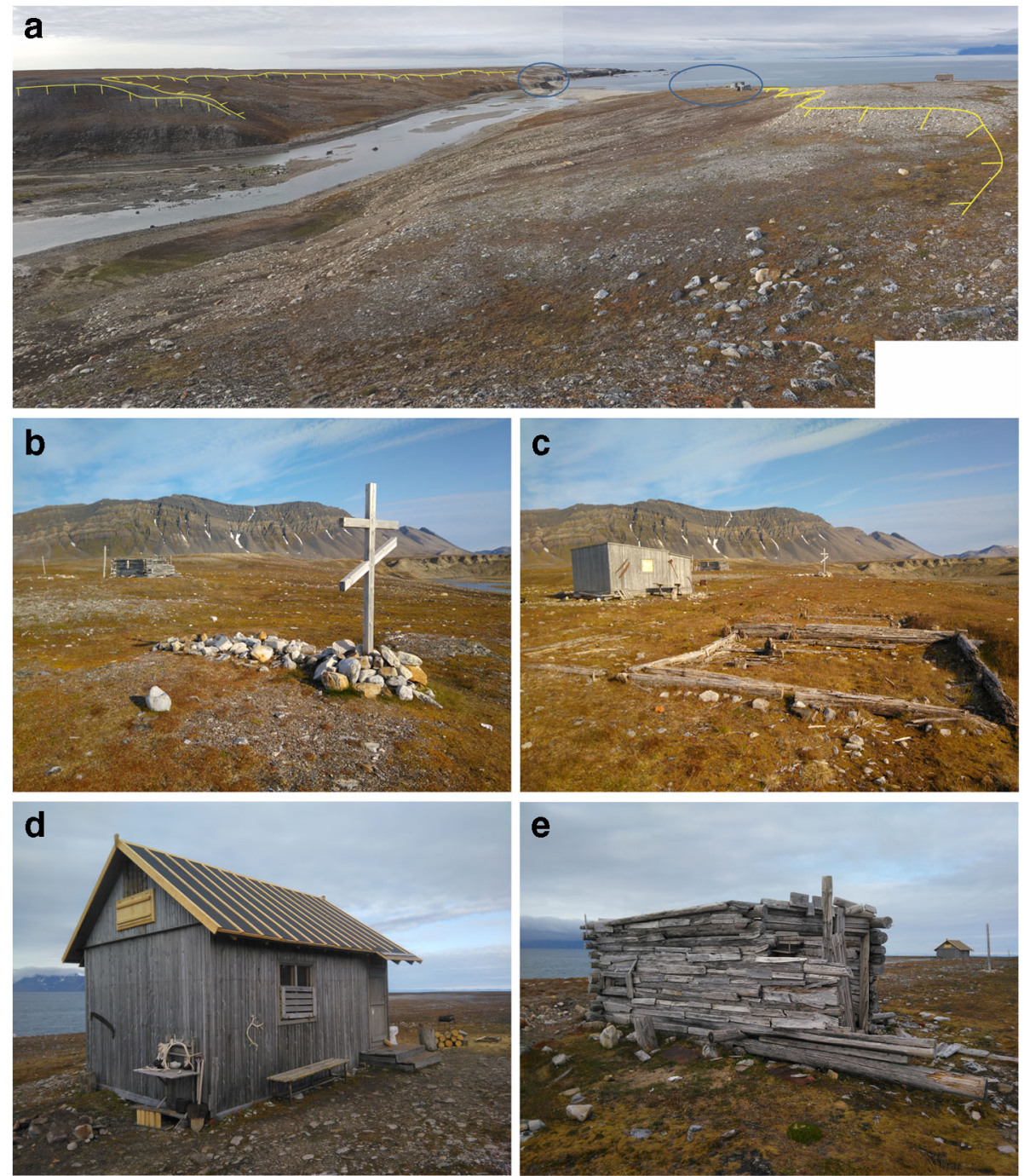

Fig. 10 Details over the cultural heritage sites located at Russekeila point; a retrogressive thaw slump scars at the mouth of the river coming from Linnévatnet Lake, in circle are represented $\mathrm{CH}$ features; $\mathbf{b}$ the restored grave and the new Russian Cross (in foreground) and the Polish research cabin (in background); $\mathbf{c}$ remains of posts in the foreground and Russekeila cabin in the background; $\mathbf{d}$ the renovated Russian cottage; e the Polish research cabin 


\section{Technical Note}

Table 1 List with the most exposed $\mathrm{CH}$ sites to thaw slump action

\begin{tabular}{|c|c|c|c|c|c|}
\hline $\begin{array}{l}\text { Heritage } \\
\text { site ID }\end{array}$ & Name & Function & $\begin{array}{l}\text { Location } \\
\text { Northing }\end{array}$ & Easting & $\begin{array}{l}\text { Location in regard to RTS } \\
\text { limit }(\mathrm{m})\end{array}$ \\
\hline $93188-1$ & Trapping cabin & Cultural memory & $\begin{array}{l}78^{\circ} 06^{\prime} \\
54^{\prime \prime}\end{array}$ & $\begin{aligned} 14^{\circ} 49^{\prime} \\
49^{\prime \prime}\end{aligned}$ & 70 (CE) \\
\hline $93224-3$ & $\begin{array}{l}\text { K4 restored grave and new Russian cross } \\
\text { (Fig. 10b) }\end{array}$ & Cultural memory & $\begin{array}{l}78^{\circ} 04^{\prime} \\
45^{\prime \prime}\end{array}$ & $\begin{array}{l}13^{\circ} 44^{\prime} \\
31^{\prime \prime}\end{array}$ & 6.5 \\
\hline $93224-4$ & $\begin{array}{l}\text { K6 remains of posts (Fig. 10c, in the } \\
\text { foreground) }\end{array}$ & Cultural memory & $\begin{array}{l}78^{\circ} 04^{\prime} \\
46^{\prime \prime}\end{array}$ & $\begin{array}{l}13^{\circ} 44^{\prime} \\
24^{\prime \prime}\end{array}$ & 45 (CE) \\
\hline $93231-1$ & Building, Russia hut & Cultural memory & $\begin{array}{l}78^{\circ} 04^{\prime} \\
43^{\prime \prime}\end{array}$ & $\begin{array}{l}13^{\circ} 43^{\prime} \\
47^{\prime \prime}\end{array}$ & 35 (CE) \\
\hline $93232-1$ & Building, house foundation & Cultural memory & $\begin{array}{l}78^{\circ} 04^{\prime} \\
43^{\prime \prime}\end{array}$ & $\begin{array}{l}13^{\circ} 44^{\prime} \\
01^{\prime \prime}\end{array}$ & 13 \\
\hline 93238-1 & Building, boat house & $\begin{array}{c}\text { Historic } \\
\text { archaeological } \\
\text { site }\end{array}$ & $\begin{array}{l}78^{\circ} 03^{\prime \prime} \\
56^{\prime \prime}\end{array}$ & $\begin{aligned} 13^{\circ} 45^{\prime} \\
45^{\prime \prime}\end{aligned}$ & 10 \\
\hline $122501-1$ & Russekeila (Fig. 10c, in the background) & Cabin & $\begin{array}{r}78^{\circ} 04^{\prime} \\
46^{\prime \prime}\end{array}$ & $\begin{array}{r}13^{\circ} 44^{\prime} \\
30^{\prime \prime}\end{array}$ & 30 (CE) \\
\hline $152074-1$ & Russian cottage (Fig. 10d) & Cabin & $\begin{array}{l}78^{\circ} 04^{\prime} \\
47^{\prime \prime}\end{array}$ & $\begin{array}{r}13^{\circ} 44^{\prime} \\
44^{\prime \prime}\end{array}$ & 66 \\
\hline $152075-1$ & Polish research cabin (Fig. 10e) & Cabin & $\begin{array}{l}78^{\circ} 04^{\prime} \\
45^{\prime \prime}\end{array}$ & $\begin{array}{r}13^{\circ} 44^{\prime} \\
36^{\prime \prime}\end{array}$ & On TS body \\
\hline
\end{tabular}

*(CE)—sites that are also under threat from coastal erosion

exposed site is shown in Fig. 1ob (site ID 93224-3). Although the grave and the Russian cross are restored, they are located at only $6.5 \mathrm{~m}$ from the closest RTS scar limit. The remains of the posts (site ID 93224-4) are the next in line and are visible in Fig. $10 \mathrm{c}$ in the foreground; they are located $45 \mathrm{~m}$ away from the closest RTS and are also vulnerable to coastal erosion. The site named Russekeila (site ID 122501-1) is visible in Fig. 10c in the background and is located at approximately $30 \mathrm{~m}$ from the closest TS limit. The Russian cottage (site ID 152074-1) visible in Fig. 1od is a renovated cabin that is in a good shape; it is located at about $65 \mathrm{~m}$ from the closest TS.

\section{Discussion}

One of our contributions resulting from this preliminary analysis was that most RTS are relatively small, which may indicate that they are recent to very recent landforms, because they did not have enough time to retrograde and reach larger elongated shapes. A similar characteristic was observed in Arctic environments, due to changing summer climate, on Banks Island (Canada) (Lewkowicz and Way 2019) and Noatak Valley, Alaska (USA) (Swanson and Nolan 2018) and in the Qinghai-Tibet Plateau (China) (Luo et al. 2019). In these cases, the RTS are not older than a few decades. This may also be due to different geological, geomorphological, vegetation, slope, aspect, permafrost and groundwater conditions. However, since most of the RTS in this Svalbard dataset are partly vegetated and show signs of secondary periglacial reworking (stone stripes and solifluction sheets), this might alternatively indicate the maximum activity of these features, if relatively simultaneous, was concentrated over a short time span. Most of the features may have been subsequently halted in the expansion, by climatic or other changes in conditions. If this secondary explanation is correct, it opens the question of what climate thresholds the specific Svalbard RTS are sensitive to and what will happen in today's rapidly warming climate. New RTS landforms may likely manifest in the future, as they are strongly correlated with increases of summer temperatures and high variability in sea ice extent and precipitations (Etzelmüller et al. 2011). Same authors have reported significant decadal warming rate at the permafrost surface $\left(0.07^{\circ} \mathrm{C} /\right.$ year $)$ associated also with active layer thickening, which in the end leads to increasing activity of all permafrostrelated gravitational processes (RTS) (Akerman 2005). Therefore, an even more detailed RTS mapping should be undertaken to provide the full picture in this threatened and rapidly changing Arctic environment. Frequent monitoring activities should take place, directly on site and remotely, to check the permafrost conditions and whether indicators of new failures can be recognised in the proximity to $\mathrm{CH}$ sites and also in proximity to other anthropic activities (such as tourism) (Holmgaard et al. 2019). A better understanding of RTS future development can help local authorities prioritise mitigation measures at known $\mathrm{CH}$ sites. Eventually, this information can be included in future multihazard approaches in the field of $\mathrm{CH}$ (Lombardo et al. 2020), in the prioritisation of disaster risk reduction (Sevieri et al. 2020), especially for the endangered Arctic CH. RTS scar inventory can also be combined with ground displacement maps, derived from Synthetic Aperture Radar Interferometry (InSAR) (Rouyet et al. 2019) in a unified approach to detect the most vulnerable $\mathrm{CH}$ sites. Other directions could be towards the spatial predictive modelling of Arctic slope processes, which represents one of our future endeavours.

\section{Conclusions}

A preliminary analysis regarding RTS distribution in the Nordenskiöld Land area of Svalbard was made. The RTS scar 
distribution was analysed in direct relation with the $\mathrm{CH}$ sites within the study area. Following our analysis, it was observed that most of the RTS scars are rounded and not elongated, which indicates that they are not older than a few decades or were active for a short period and have been quiescent ever since. The noted presence of a periglacially reworked surface on many RTS supports the latter theory. Both alternatives indicate a strong possibility that a continued warming permafrost on Svalbard might reactivate small active or previously active TS and RTS. The same behaviour has been identified in other permafrost areas of the globe, such as northern Canada, northern USA and the Tibetan Plateau of China, where RTS development is known to be related to a general temperature increase over the last decades. Concerning RTS size, few scars appear to be larger than $20,000 \mathrm{~m}^{2}$ and longer than $300 \mathrm{~m}$. Following size analysis of the RTS in a traditional Frequency Area Distribution plot, it was found that the power law exponent is approximately -2.2 , which aligns well with analogous landslide inventories mapped in non-Arctic landscapes. When analysing the RTS and $\mathrm{CH}$ sites densities, it can be observed that RTS and $\mathrm{CH}$ sites do not significantly overlap, with the exception of the north-west (Colesbukta, Grønfjorden, Kapp Starostin), north-east (Sassendalen and Sassenfjorden) and south-west (Van Muydenbukta) coastlines. This highlights the fact that at the present moment, there are no big concerns regarding the RTS affecting $\mathrm{CH}$ sites on a large scale in Svalbard. The nine sites identified as being the closest to thaw slumping were presented. They should be prioritised by the local authorities in any future planning or mitigation measures towards the $\mathrm{CH}$ of Nordenskiöld Land area, Svalbard.

\section{Acknowledgements}

Alma E. Thuestad (NIKU) is kindly acknowledged for her help in compiling the cultural heritage database for Svalbard. We are grateful for the constructive comments of two anonymous reviewers.

Open Access This article is licensed under a Creative Commons Attribution 4.0 International License, which permits use, sharing, adaptation, distribution and reproduction in any medium or format, as long as you give appropriate credit to the original author(s) and the source, provide a link to the Creative Commons licence, and indicate if changes were made. The images or other third party material in this article are included in the article's Creative Commons licence, unless indicated otherwise in a credit line to the material. If material is not included in the article's Creative Commons licence and your intended use is not permitted by statutory regulation or exceeds the permitted use, you will need to obtain permission directly from the copyright holder. To view a copy of this licence, visit http://creativecommons.org/licenses/by/ $4.0 /$.

\section{References}

Akerman HJ (2005) Relations between slow slope processes and active-layer thickness 1972-2002, Kapp Linné, Svalbard. Norsk Geografisk Tidsskrift - Nor J Geogr 59(2):116-128. https://doi.org/10.1080/00291950510038386

Arlov TB (1989) A Short History of Svalbard, 2nd edn. Norsk Polarinstitutt, Oslo

Askeladden - Riksantivaren. (2020) Norwegian Directorate for Cultural Heritage Management. https://www.riksantikvaren.no/veiledere/askeladden/. Accessed 04 July 2020.

Biskaborn BK, Smith SL, Noetzli J, Matthes H, Vieira G, Streletskiy DA, Schoeneich P, Romanovsky VE, Lewkowicz AG, Abramov A, Allard M, Boike J, Cable WL, Christiansen HH, Delaloye R, Diekmann B, Drozdov D, Etzelmüller B, Grosse G, Guglielmin M, Ingeman-Nielsen $T$, Isaksen $K$, Ishikawa $M$, Johansson $M$, Johannsson $H$, Joo $A$, Kaverin D, Kholodov A, Konstantinov P, Kröger T, Lambiel C, Lanckman JP, Luo D, Malkova G, Meiklejohn I, Moskalenko N, Oliva M, Phillips M, Ramos M, Sannel ABK, Sergeev D, Seybold C, Skryabin P, Vasiliev A, Wu Q, Yoshikawa K, Zheleznyak M, Lantuit H (2019) Permafrost is warming at a global scale. Nat Commun 10:264. https://doi.org/ 10.1038/s41467-018-08240-4

Capizzi P, Martorana R (2014) Integration of constrained electrical and seismic tomographies to study the landslide affecting the cathedral of Agrigento. J Geophys Eng 11(4):045009

Cassidy AE, Christen A, Henry GHR (2017) Impacts of active retrogressive thaw slumps on vegetation, soil, and net ecosystem exchange of carbon dioxide in the Canadian High Arctic. Arctic Sci 3:179-202. https://doi.org/10.1139/as-2016-0034

Castro Camilo D, Lombardo L, Mai PM, Huser R (2017) Handling high predictor dimensionality in slope-unit-based landslide susceptibility models through LASSOpenalized Generalized Linear Model. Environ Model Softw 97:145-156. https:// doi.org/10.1016/j.envsoft.2017.08.003

Council of the European Union (2020). https://www.consilium.europa.eu/media/44116/ st08208-en20.pdf. Accessed 25 June 2020.

Dahle K, Bjerck HB, Prestvold K (2000) Kulturminneplan for Svalbard 2000-2010. Cultural heritage plan for Svalbard 2000-2010. Longyearbyen, Governor of Svalbard. Sysselmannens Rapportserie 2, pp.126. https://www2.sysselmannen.no/globalassets/ sysselmannen-dokument/trykksaker/kulturminneplan_2am0y.pdf Accessed 04 July 2020.

Eckerstorfer M, Malnes E, Christiansen HH (2017) Freeze/thaw conditions at periglacial landforms in Kapp Linné, Svalbard, investigated using field observations, in situ, and radar satellite monitoring. Geomorphology 293:433-447. https://doi.org/10.1016/ j.geomorph.2017.02.010

Etzelmüller B, Schuler TV, Isaksen K, Christiansen HH, Farbrot H, Benestad R (2011) Modeling the temperature evolution of Svalbard permafrost during the 20th and 21st century. Cryosphere 5:67-79. https://doi.org/10.5194/tc-5-67-2011

Fall M, Azzam R, Noubactep C (2006) A multi-method approach to study the stability of natural slopes and landslide susceptibility mapping. Eng Geol 82(4):241-263. https:// doi.org/10.1016/j.enggeo.2005.11.007

Fatorić S, Seekamp E (2017) Are cultural heritage and resources threatened by climate change? A systematic literature review. Clim Chang 142(1-2):227-254. https:// doi.org/10.1007/s10584-017-1929-9

Governor of Svalbard. (2020) https://www.sysselmannen.no/en/the-governor-of-svalbard/environmental-protection/cultural-heritage-management/. Accessed 04 July 2020 .

Guzzetti F, Mondini AC, Cardinali M, Fiorucci F, Santangelo M, Chang KT (2012) Landslide inventory maps: New tools for an old problem. Earth Sci Rev 112(1-2):42-66. https:// doi.org/10.1016/j.earscirev.2012.02.001

Hacquebord L (2001) Three centuries of whaling and walrus hunting in Svalbard and its impact on the Arctic ecosystem. Environ Hist 7(2):169-180

Highland LM, Bobrowsky P (2008) The landslide handbook - a guide to understanding landslides, 1325th edn. U.S. Geological Survey Circular, Reston, p 129

Hollesen J, Callanan M et al (2018) Climate change and the deteriorating archaeological and environmental archives of the Arctic. Antiquity 92(363):573-586. https://doi.org/ 10.15184/aqy.2018.8

Holmgaard SB, Thuestad AE, Myrvoll ER, Barlindhaug S (2019) Monitoring and managing human stressors to coastal cultural heritage in Svalbard. Humanities 8(1):21. https:// doi.org/10.3390/h8010021

Hu B, Wu Y, Zhang X, Yang B, Chen J, Li H, Chen X, Chen Z (2019) Monitoring the thaw slump-derived thermokarst in the Qinghai-Tibet plateau using satellite SAR 
interferometry. Hindawi J Sensors 2009:1698432-1698438. https://doi.org/10.1155/ 2019/1698432

Huang L, Luo J, Lin Z, Niu F, Liu L (2020) Using deep learning to map retrogressive thaw slumps in the Beiluhe region (Tibetan Plateau) from CubeSat images. Remote Sens Environ 237:111534. https://doi.org/10.1016/j.rse.2019.111534

Humlum 0 (2002) Modelling late 20th-century precipitation in Nordenskiöld Land, Svalbard, by geomorphic means. Norsk Geografisk Tidsskrift - Nor J Geogr 56:96103. https://doi.org/10.1080/002919502760056413

Humlum 0, Instanes A, Sollid JL (2003) Permafrost in Svalbard; a review of research history, climatic background and engineering challenges. Polar Res 22:191-215. https://doi.org/10.1111/j.1751-8369.2003.tb00107.x

Hungr 0, Leroueil S, Picarelli L (2014) The Varnes classification of landslide types, an update. Landslides 11(2):167-194. https://doi.org/10.1007/s10346-013-0436-y

Iverson RM (1997) The physics of debris flows. Rev Geophys 35(3):245-296

Jibson RW, Tanya H H (2020) The influence of frequency and duration of seismic ground motion on the size of triggered landslides - a regional view. Eng Geol 273:105671. https://doi.org/10.1016/j.enggeo.2020.105671

Johansen B, Tømmervik H (2014) The relationship between phytomass, NDVI and vegetation communities on Svalbard. Int J Appl Earth Obs 27:20-30. https:// doi.org/10.1016/j.jag.2013.07.001

Kokelj SV, Lacelle D, Lantz TC, Tunnicliffe J, Malone L, Clark ID, Chin KS (2013) Thawing of massive ground ice in mega slumps drives increases in stream sediment and solute flux across a range of watershed scales. J Geophys Res Earth Surf 118:681-692. https://doi.org/10.1002/jgrf.20063

Lacelle D, Bjornson J, Lauriol B (2010) Climatic and geomorphic factors affecting contemporary (1950-2004) activity of retrogressive thaw slumps on the Aklavik Plateau, Richardson Mountains, NWT, Canada. Permafr Periglac Process 21:1-15. https://doi.org/10.1002/ppp.666

Lewkowicz AG, Way RG (2019) Extremes of summer climate trigger thousands of thermokarst landslides in a high Arctic environment. Nat Commun 10:1329. https:// doi.org/10.1038/s41467-019-09314-7

Li Z, Shi W, Lu P, Yan L, Wang Q, Miao Z (2016) Landslide mapping from aeria photographs using change detection-based Markov random field. Remote Sens Environ 187:76-90. https://doi.org/10.1016/j.rse.2016.10.008

Lombardo L, Mai PM (2018) Presenting logistic regression-based landslide susceptibility results. Eng Geol 244:14-24. https://doi.org/10.1016/j.enggeo.2018.07.019

Lombardo L, Tanya] H, Nicu IC (2020) Spatial modeling of multi-hazard threat to cultural heritage sites. Eng Geol 277:105776. https://doi.org/10.1016/j.enggeo.2020.105776

Lønne I (2005) Faint traces of high Arctic glaciations: an early Holocene ice-front fluctuation in Bolterdalen, Svalbard. Boreas 34:308-323. https://doi.org/10.1111/ j.1502-3885.2005.tb01103.x

Lousada M, Vieira G, Bandeira L, Mora C (2018) Evaluation of the use of very high resolution aerial imagery for accurate ice-wedge polygon mapping (Adventdalen, Svalbard). Sci Total Environ 615:1574-1583. https://doi.org/10.1016/ j.scitotenv.2017.09.153

Luo J, Niu F, Lin Z, Liu M, Yin G (2019) Recent acceleration of thaw slumping in permafrost terrain of Qinghai-Tibet Plateau: an example from the Beiluhe Region. Geomorphology 341:79-85. https://doi.org/10.1016/j.geomorph.2019.05.020

Malamud BD, Turcotte DL, Guzzetti F, Reichenbach P (2004) Landslide inventories and their statistical properties. Earth Surf Process Landf 29(6):687-711. https://doi.org/ 10.1002/esp.1064

Margottini C (2004) Instability and geotechnical problems of the Buddha niches and surrounding cliff in Bamiyan Valley, central Afghanistan. Landslides 1(1):41-51 https://doi.org/10.1007/s10346-003-0010-0

Mihu-Pintilie A, Nicu IC (2019) GIS-based landform classification of eneolithic archaeological sites in the plateau-plain transition zone (NE Romania): habitation practices vs. flood hazard perception. Remote Sens 11(8):915. https://doi.org/10.3390/rs11080915

Nicu IC (2017) Frequency ratio and GIS-based evaluation of landslide susceptibility applied to cultural heritage assessment. J Cult Herit 28:172-176. https://doi.org/ 10.1016/j.culher.2017.06.002

Nicu IC (2019) Natural risk assessment and mitigation of cultural heritage sites in Northeastern Romania (Valea Oii river basin). Area 51(1):142-154. https://doi.org/10.1111/ area.12433

Nicu IC, Asă ndulesei A (2018) GIS-based evaluation of diagnostic areas in landslide susceptibility analysis of Bahluiet River Basin (Moldavian Plateau, NE Romania). Are
Neolithic sites in danger? Geomorphology 314:27-41. https://doi.org/10.1016/ j.geomorph.2018.04.010

Nicu IC, Stoleriu CC (2019) Land use changes and dynamics over the last century around churches of Moldavia, Bukovina, Northern Romania - challenges and future perspectives. Habitat Int 88:101979. https://doi.org/10.1016/j.habitatint.2019.04.006

Nicu IC, Usmanov B, Gainullin I, Galimova M (2019) Shoreline dynamics and evaluation of cultural heritage sites on the shores of large reservoirs: Kuibyshev Reservoir, Russian Federation. Water 11(3):591. https://doi.org/10.3390/w11030591

Nicu IC, Stalsberg K, Rubensdotter L, Martens VV, Flyen A-C (2020) Coastal erosion affecting cultural heritage in Svalbard. A case study in Hiorthhamn (Adventfjorden) an abandoned mining settlement. Sustainability 12(6):2306. https://doi.org/10.3390/ su12062306

Nitze I, Grosse G, Jones BM, Romanovsky VE, Boike J (2018) Remote sensing quantifies widespread abundance of permafrost region disturbances across the Arctic and Subarctic. Nat Commun 9:5423. https://doi.org/10.1038/s41467-018-07663-3

Niu F, Luo J, Lin Z, Ma W, Lu J (2012) Development and thermal regime of a thaw slump in the Qinghai-Tiber plateau. Cold Reg Sci Technol 83-84:131-138. https://doi.org/ 10.1016/j.coldregions.2012.07.007

Norwegian Polar Institute. (2020) https://toposvalbard.npolar.no. Accessed 07 July 2020. Norwegian Polar Institute / USGS Landsat. (2020) https://geodata.npolar.no/. Accessed 04 July 2020.

Regulation No. 1186 on the protection of Nordenskiöld Land National Park, Svalbard (2003) https://www.informea.org/en/legislation/regulation-no-1186-protectionnordenski\%C3\%B6ld-land-national-park-svalbard. Accessed 04 July 2020

Rouyet L, Lauknes TR, Christiansen HH, Strand SM, Larsen Y (2019) Seasonal dynamics of a permafrost landscape, Adventdalen, Svalbard, investigated by InSAR. Remote Sens Environ 231:111236. https://doi.org/10.1016/j.rse.2019.111236

Schuur EAG, McGuire AD, Schädel C, Grosse G, Harden JW, Hayes DJ, Hugelius G, Koven CD, Kuhry $P$, Lawrence DM, Natali SM, Olefeldt D, Romanovsky VE, Schaefer K, Turetsky MR, Treat CC, Vonk JE (2015) Climate change and the permafrost carbon feedback. Nature 520:171-179. https://doi.org/10.1038/nature14338

Séjourné A, Costard F, Fedorov A, Gargani J, Skorve J, Massé M, Mège D (2015) Evolution of the banks of thermokarst lakes in Central Yakutia (Central Siberia) due to retrogressive thaw slump activity controlled by insolation. Geomorphology 241:3140. https://doi.org/10.1016/j.geomorph.2015.03.033

Sessford EG (2013) Spatial and temporal analysis of holocene coastal development: applications to erosion assessment and cultural heritage mitigation in Svalbard. Master's Thesis, University of Oslo.

Sevieri G, Galasso C, D'Ayala D et al (2020) A multi-hazard risk prioritization framework for cultural heritage assets. Nat Hazards Earth Syst Sci 20:1391-1414. https://doi.org/ 10.5194/nhess-20-1391-2020

Sun Z, Wang Y, Sun Y, Niu F, Li G, Gao Z (2017) Creep characteristics and process analyses of a thaw slump in the permafrost region of the Qinghai-Tibet Plateau, China. Geomorphology 293:1-10. https://doi.org/10.1016/j.geomorph.2017.04.045

Swanson DK, Nolan M (2018) Growth of retrogressive thaw slumps in Noatak Valley, Alaska, 2010-2016, measured by airborne photogrammetry. Remote Sens 10:983. https://doi.org/10.3390/rs10070983

Sysselmannen (2016) Bosetninger på Svalbard. Sysselmannen på Svalbard, Longyearbyen Tanya L H, Lombardo L (2020) Completeness index for earthquake-induced landslide inventories. Eng Geol 264:105331. https://doi.org/10.1016/j.enggeo.2019.105331

Tanya H H, Allstadt KE, van Westen CJ (2018) An updated method for estimating landslide-event magnitude. Earth Surf Process Landf 43(9):-[1836-[1847. https:// doi.org/10.1002/esp.4359

Tanyal H, van Westen CJ, Allstadt KE, Jibson RW (2019) Factors controlling landslide frequency - area distributions. Earth Surf Process Landf 44(4):900-917. https:// doi.org/10.1002/esp.4543

Tarolli P, Sofia G, Dalla Fontana G (2012) Geomorphic features extraction from highresolution topography: landslide crowns and bank erosion. Nat Hazards 61:65-83. https://doi.org/10.1007/s11069-010-9695-2

Tarragüel AA, Krol B, van Westen C (2012) Analysing the possible impact of landslides and avalanches on cultural heritage in Upper Svaneti, Georgia. J Cult Herit 13(4):453461. https://doi.org/10.1016/j.culher.2012.01.012

Turetsky MR, Abbott BW, Jones MC, Anthony KW, Olefeldt D, Schuur EAG, Grosse G, Kuhry P, Hugelius G, Koven C, Lawrence DM, Gibson C, Sannel ABK, McGuire AD (2020) Carbon release through abrupt permafrost thaw. Nat Geosci 13:138-143. https://doi.org/10.1038/s41561-019-0526-0 
van Pelt W, Pohjola V, Pettersson R, Marchenko S, Kohler J, Luks B, Hagen JO, Schuler TV, Dunse T, Noël B, Reijmer C (2019) A long-term dataset of climatic mass balance, snow conditions, and runoff in Svalbard (1957-2018). Cryosphere 13:2259-2280. https:// doi.org/10.5194/tc-13-2259-2019

Wang B, Paudel B, Li H (2016) Behaviour of retrogressive thaw slumps in northern Canada - three-year monitoring results from 18 sites. Landslides 13:1-8. https:// doi.org/10.1007/s10346-014-0549-y

I. C. Nicu

High North Department, Norwegian Institute for Cultural Heritage Research (NIKU),

Fram Centre,

N-9296, Tromsø, Norway
L. Lombardo (- $)$

Faculty of Geo-Information Science and Earth Observation (ITC), University of Twente,

PO Box 2177500, Enschede, AE, Netherlands

Email: I.lombardo@utwente.nl

L. Rubensdotter

Geological Survey of Norway (NGU),

P.0. Box 6315 Torgarden, 7491, Trondheim, Norway

L. Rubensdotter

Arctic Geology Department,

The University Centre in Svalbard (UNIS),

P.0. Box 156, 9171, Longyearbyen, Norway 